The Social Sciences 6(2): 164-168, 2011

ISSN: $1818-5800$

(C) Medwell Journals, 2011

\title{
A Review of the Impact of HIV/AIDS on Education, the Workforce and Workplace: The African Experience
}

\author{
${ }^{1}$ G.R.I. Pennap, ${ }^{2} \mathrm{M}$. Chaanda and ${ }^{3} \mathrm{~L}$. Ezirike \\ ${ }^{1}$ Department of Biological Sciences, ${ }^{2}$ Department of Geology and Mining, \\ ${ }^{3}$ Department of General Studies, Nasarawa State University, P.M.B. 1022, Keffi, Nigeria
}

\begin{abstract}
The impact of HIV/AIDS cuts across all sectors of economic activities and social life. For example, it not only reduces the stock of human capital but also the capacity to maintain the required turnover of many sought after skills and training like engineers, doctors, teachers, artisans and others. In the educational sphere, it leads to among other things a decrease in potential clientele for education, resources and even donor support. On the workforce, its impact increases expenditure on the one hand and decreases productivity on the other. In fact, economists posit that even when unemployment rates are high, retirement and death of a large number of skilled and unskilled workers will cause an increase in wages.
\end{abstract}

Key words: HIV/AIDS, education, workforce, workplace, economic, Africa

\section{INTRODUCTION}

Gudmund Hernes referred to the Human Immunodeficiency Virus (HIV) as a virus that in principle is simple to avoid and is not particularly contagious but the most deadly because it embodies itself in the most vital of forces especially, the biological urge that keeps human beings going. Hence, the epidemic penetrates, the core of social life: rights of woman, norms of abstinence and masculinity, workplace behavior, conventions of family life and privacy and also the concept of $\sin$, decency, lust, deviance, prostitution and drug addiction. It therefore, infiltrates not only the code of life but the core of the private lives and sometimes the secret lives. Within the period of 2 decades, the HIV/AIDS epidemic has become a global development disaster with implications for health, human development, food production, economy, national security and the likes. It has also gradually become a leading cause of morbidity and mortality amongst those in their reproductive and economically productive years (Frank, 2005). For example, projections of current rates in Nigeria show that by 2007 , nearly $19 \%$ of the total population in Nigeria could be living with HIV/AIDS. The impact if this epidemic cannot be underestimated because it cuts across all areas of social life and economic activities. However, HIV/AIDS does not affect all work places in the same way because despite all odds, the demand for some services increase as the epidemic spread and so profit margin increases. Such workplaces include pharmaceutical companies and retailers, healthcare providers, mortuary firms and casket makers. The bulk of the prevalence of HIV/ADS is among the youth especially those in the age of high sexual activity. So far, it has been reported that in this part of the world, women are disproportionately affected because of their status in the society. As a result of this epidemic, life expectancy has dropped in most countries. For example, Botswana, Zambia and Zimbabwe were projected to have had life expectancies of 60-70 years without HIV/ADS but with this scourge, it is expected that they will have life expectancies of only 30 years.

In 2009 alone, an estimated 1.3 million adults and children died as a result of HIV/AIDS in sub-Saharan Africa. The director of UNAIDS Peter Piot had posited that without education, AIDS will continue its rampant spread. With ADS out of control, education will be out of reach (World Bank/UNESCO/UNAIDS Press Release, 2002).

The impact of HIV/AIDS on education: The fact that education is critical for positive economic development, emancipation and general well being cannot be underscored. However, since the scourge of HIV/AIDS, there has been a real threat to the education sector. The relationship between HIV/AIDS and education is circular because as the epidemic gets worse, the education system is damaged which can lead to an increase in the incidence of the infection.

The impact of HIV/AIDS on education creates a host of problems that threaten to overwhelm the structure of educational organization, management and even provision. This is because providing education in an HIV

Corresponding Author: G.R.I. Pennap, Department of Biological Sciences, Nasarawa State University, P.M.B. 1022, Keffi, Nigeria 
infected population is different from that in the virus free population. However, education is required to slow down the transmission of HIV and modify its impact in all facets of life. In the world of research, a global estimate of 36.5 million people of working age are reported to be infected by HIV and the global labour force to have lost 28 million workers due to AIDS since, the advent of the epidemic. Education is the most effective way of preventing HIV infection and also reducing discrimination against people living with HIV/AIDS both within and outside the workplace.

Impact of pupils and school enrolment: At the micro level, it has a long term effect of there being fewer pupils to educate since population is depleting by the day. It had been projected that in Botswana, Malawi, Zambia, Zimbabwe and other countries in sub-Saharan Africa by 2010 , the population will be considerably smaller than if there had been no HIV/AIDS epidemic (Hunter and Fall, 1998). This demographic development will also reduce the number of pupils of primary school age. There is also the decline in school attending by pupils because they have been orphaned so cannot afford the fees or might have been turned into caregivers. For many African children, this inability to enroll in school is HIV/AIDS related (UNICEF, 1996).

The decline in school enrolment rate also has a negative impact as the epidemic because a good basic education is one of the most effective and cost effective means of preventing HIV (World Bank, 2002). In Swaziland and the Central African Republic, school enrolment fell by $25-30 \%$ at the beginning of the millennium due to HIV/AIDS scourge (UNAIDS, 2002).

\section{Impact on teachers and teaching}

Teacher mortality: This index affects teaching. The World Bank (1992) projected that by 2010 and 2020, 14,460 and 20,200 teachers, respectively would have died from HIV/AIDS in Tanzania. With such monumental losses, the education sector is disadvantaged in terms ratio of teachers to pupils. A study in South Africa reported that $21 \%$ of teachers aged 25-34 were living with HIV/AIDS. Another scenario from Tanzania estimated the need for 45,000 teachers to make up for those that have died or resigned because of $\mathrm{HIV} / \mathrm{AIDS}$. Most of these according to the Tanzania's teachers union are experienced staff aged 41-50 years (UNAIDS, 2006).

Teacher productivity: A study in Zambia (Milimo, 1998) indicated that reports from school authorities, Parents Teachers' Association and communities complained of loss of teaching time due to illness of teachers. With the expected AIDS related sickness episodes, the involvement of sick teachers in school activities become progressively episodic. When a teacher falls ill, the class may either be taken by another teacher, combined with another class or even left untaught.

Teacher costs: The services of sick teachers cannot be terminated even when they are obviously non-productive. This implies a high salary cost plus the financial cost of replacement through short and long term ventures.

Teachers stress: Teachers also have to contend with the stress of the affliction among their students, colleagues and family members. This affects them psychologically and may even affect their productivity. In Zambia, HIV/AIDS education and counseling have had to be incorporated into Teacher training programmes to help prepare these teachers for such eventualities (Zambia Ministry of Education, 1999).

Impact on availability of resources for education: HIV/AIDS affects the availability of resources for education. UNDP (1999) posited that because of HIV/AIDS global economic growth is $1.4 \%$ lower then it would have been without the epidemic. Absenteeism due to illness, time off for funerals and a less experienced labour force will result in reduced productivity and consequently lower revenue generation. It has also led to increased spending on health care cost, burial expenses and training of replacement employees at the expense of educational needs. Donors see HIV/AIDS as causing a lot of human suffering, increasing poverty, reducing productivity and even reversing the development gains they have always promoted. They are therefore more interested in HIV/AIDS problems and how to cope with its impact. This therefore, leaves a comparatively less commitment to the education sector.

Impact on potential clientele for education: There is a decrease in the number of children being born these days as a result of HIV/AIDS. While some are born HIV positive and so are likely to die before school age, other parents cannot afford to have any more children as a result of their status. Another reason for this decline might be the presence of a widow or a widower.

There is an increase in the number of children orphaned by the scourge. The economical and psychological burdens on the extended family usually pose a problem. Many of these children have to work in order to support themselves or their siblings thus are unable to register in school or become care givers so that those already in school remain. Some are so traumatized 
by the pain of loss that they are unable to concentrate and learn while others are at risk of contracting HIV/AIDS through income generating practices like prostitution.

Impact on content of education: The main impact of HIV/AIDS on education is of its incorporation into the curriculum. In Zambia, they are revising the school curriculum to address the attitude and behavior of youth through the inclusion of life skills and reproductive health programmes (Zambia Ministry of Education, 1999). The World Bank (1997) posited that HIV/AIDS education is likely to be a good investment in preventing HIV. It went ahead in 1999 to deal with the epidemic in sub-Saharan Africa by giving more prominence to the roles that can be played by education related interventions, e.g., educating girls, expanding gender initiatives, reducing poverty, strengthening capacity building, mainstreaming HIV/AIDS in all bank activities and redirecting ongoing project funds to HIV/AIDS activities.

The impact of HIV/ADS on the work place and work force: Most of the people living with HIV/AIDS in Africa are between the ages of $15-49$ which is the prime age of their working lives.

In 2005, Frank studied that HIV/AIDS is one of the biggest causes of mortality in the workforce. Furthermore, the internal labour organization estimated in 2005 that 2 million workers globally were unable to work due to HIV/AIDS and related illnesses.

This figure is expected to double to 4 million by 2015 . The international Labour Organization (ILO) estimated that by 2010 , the total force will be over $9 \%$ smaller in 35 countries of sub-Saharan Africa affected by the HIV/AIDS scourge with $>20 \%$ losses of total labour supply in most of the affected countries. It also noted that by 2015 there will be further losses of up to $12 \%$ with labour supply of $30-40 \%$ smaller in countries with very high prevalence. This is expected to affect productivity on income in the economy (Economic Commission for Africa, 2004). In the African workplace, some major factors fueling the epidemic have been identified (Economic Commission for Africa, 2004) as:

- $\quad$ Illiteracy

- Business dominated by men, especially when located in rural areas

- Access to free or subsidized alcohol and tendency for alcohol abuse

- Frequent travel outside one's permanent place of work

- Location in border towns or transit areas
- Industries dominated by seasons

- Workplace located far from permanent residence

- Access to reasonable levels of income in the midst of poverty

Adults of working age whether or not they are formally considered labour force participants may have to drop economically productive activities to provide care for the sick. This indirect impact of care therefore, doubles the direct impact of the illness especially as it is reported for Africa, Asia, Latin America and the Caribbean (Whiteside and Windshury, 1996).

Lisk posited that the effect of HIV/AIDS on the labour force and on all persons of working age are measurable in their overall impact on economic growth and development. On the whole, there is decreased productivity due to followings:

Increased absenteeism: This includes absence of infected persons and care givers from work and also other employee absence to attend funerals of coworkers or relatives. A South African sugar company posited that HIV positive employees took a total of 55 days off as sick leave in the last 2 years of their lives (Bill, 2005). East African businesses have reported absenteeism as accounting for $25-54 \%$ of company costs (UNAIDS, 2003). In a study, out of 1000 companies in Southern Africa, 9\% reported a significant negative impact due to AIDS.

Increased unskilled labour: Unskilled labour is increased by the number of children who are forced into labour as a result of parental or guardian incapacitation or loss due to HIV/AIDS. This ultimately threatens the goals of eliminating child labour and promoting sustainable development.

Loss of experienced and skilled labour: This results from untimely retirement due to ill health, employee death and hiring of ad-hoc staff to fill in the gap due to absenteeism. The epidemic is most prevalent among the 15-49 years age group which comprises a large number of the workforce. This further implies that the impact may be larger than the absolute number of AIDS that death indicate.

The epidemic therefore reduces the stock of skills and experience of the labour force which further threatens the goal of poverty reduction. It is estimated that the annual per capital growth in half of the countries in sub-Saharan Africa is falling by $0.5-1.2 \%$ as a direct result of AIDS. By 2010, per capital Gross Domestic Product (GDP) in some of the hardest hit countries is likely to drop by $8 \%$ and per capital consumption may even fall further. 
Increased cost: The direct cost implication of this epidemic on the workplace include an increase in recruitment, training and retraining cost, death benefits, provision of medical assistance, life and safety insurance policy and it also shortens the accumulation period for retirement funds.

For example, Gold field in South Africa reported in 2001 that HIV/AIDS accounted for 1/4 of total company medical costs, 3/4 of all company funeral costs and was responsible for all costs associated with death-in service benefits (Bill, 2005).

Guinness Nigeria, supports the cost of treatment for a life time of its employees and dependants suffering from $\mathrm{HIV/ADS}$ related illness. In fact, economists have shown that even where unemployment rates are high retirement and death of large skilled and unskilled workers will put an upward pressure on wages (Bill, 2005).

Impact on trade unionism: On the whole, HIV/AIDS can lead to the loss or incapability of key staff and activists. This can lead to poor organizing skills, defect in support to membership reduce membership, strength and consequently reduced financial strength.

Impact mitigation: The success of any impact mitigation rests on both management and employee representatives. They have the important role of identifying and addressing situations and practices that increase risks to individuals and consequently workplace. A milestone has been achieved by many companies. In Africa as reported by Economic Commission for Africa (2004), the response to the competitive pressures of globalization has turned out to be a solution to the menace of the viral infection whereby workplaces have been cutting or limiting employee benefits, changing the structure of employment contracts, outsourcing unskilled jobs, carrying out selective retrenchment or non-voluntary medical retirements or mechanizing tasks that previously required human effort. Suffice to say there are innumerable strategies that can be put.

In place to strengthen the response as well as mitigate the impact of HIV/AIDS in education, the workforce and workplace. Success can only be achieved if government make the HIV/AIDS issue a problem to tackle and not to be avoided. In this wise, stimulating and supporting a broad multi-sectoral approach geared at mobilization, prevention, care and support will go a long way in mitigation.

For example, the Nigerian government has set up a National framework which provides opportunities for better programming and the establishment of stronger self coordinating coalitions by all stakeholders. In a similar way, his excellency Alhaji Aliu Mahama, former Vice President of Ghana said at the workplace, the problem should be faced squarely, candidly and with compassion by both employers and employees. Continuous education of the workforce on the disease is imperative and clear government policies are necessary to drive the workplace programmes (Economic Commission of Africa, 2004). For example in Swaziland, there is an anti-AIDS coalition which promotes voluntary counseling and testing (IRINnews.org, 2005) while in Botswana, workers of the Debswana diamond company are entitled to free HIV testing as well as free antiretroviral drugs (News from Africa, 2003).

\section{REFERENCES}

Bill, R., 2005. Workplace HIV/AIDS Program: An Action Guide for Managers. USAID, Geneva.

Economic Commission for Africa, 2004. Report on the commission on HIV/AIDS and Governance in Africa. HIV/AIDS and the World of Work.

Frank, O., 2005. HIV/AIDS and Work: Global Estimates, Impact and Response. The World of Work, USA., pp: $1-5$.

Hunter, S. and D. Fall, 1998. An assessment of Orphans in the context of children Affected by HIV/AIDS. Draft Report for UNICEF, Lusaka.

IRINnews.org, 2005. SWAZILAND: Business coalition launches HIV/AIDS mitigation plan. http://www.irin news.org/report.aspx?reportid $=54109$.

Milimo, J.T., 1998. Factors affecting school attendance. A qualitative approach. A Report for UNESCO.

News from Africa, 2003. Mining giants fights workplace HIV/ADS. http:/www.news fromafrica.org/newsfrom africa/articles/art_1252.html.

UNAIDS, 2002. Report on the Global AIDS Epidemic. UNAIDS, Geneva.

UNAIDS, 2003. HIV/AIDS, It's Your Business. UNAIDS, Geneva.

UNAIDS, 2006. Report on the global AIDS epidemic. The Impact of AIDS on People and Societies, Chapter 4.

UNDP, 1999. Verbal report to Sub-Saharan Africa education for all. 2000 Conference, Johannesburg, 7 th December.

UNICEF, 1996. Training in classroom: Stress management for primary school teachers. Evaluation of Pilot Project, Lusaka.

Whiteside, A. and R. Windshury, 1996. Vancouver AIDS conference: Special report. Zambia criticised for missed opportunities. AIDS Anal. Afr., 6: 3-3.

World Bank, 1992. Tanzania: AIDS Assessment and Planning Study. The World Bank, Washington DC. USA. 
World Bank, 1997. Confronting AIDS: Public priorities in a global epidemic. A World Bank Policy Research Report. Oxford.

World Bank, 2002. Education and HIV/AIDS: A Window of Hope. World Bank Publications, USA., ISBN-10: 0821351176.
World Bank/UNESCO/UNAIDS Press Release, 2002. In turning the tide against HIV/AIDS, education is key. http://portal.unesco.org/es/ev.php-URL_ID $=7195 \&$ URL_DO=DO_TOPIC\&URL_SECTION $\overline{\mathrm{N}}=201 \mathrm{html}$. Zambia Ministry of Education, 1999. Education our future. National Policy on Education. 